\title{
Reproduction and growth of the Southern Leopard Frog, Lithobates sphenocephalus (Cope, 1886), in Virginia: implications for seasonal shifts in response to global climate change
}

\author{
Daniel F. Hughes ${ }^{1,}$, Walter E. Meshaka, Jr.'2, Pablo R. Delis ${ }^{3}$ \\ ${ }^{1}$ Department of Biological Sciences, University of Texas at El Paso, 500 West University Avenue, El Paso, \\ Texas 79968, U.S.A. \\ 2 Section of Zoology and Botany, State Museum of Pennsylvania, 300 North Street, Harrisburg, Pennsylva- \\ nia 17120, U.S.A. \\ 3 Department of Biology, Shippensburg University, 1871 Old Main Drive, Shippensburg, Pennsylvania \\ 17257, U.S.A. \\ *Correspondence: E-mail: dfhughes@miners.utep.edu
}

Received: 28 November 2016; returned for review: 20 January 2017; accepted 13 March 2017.

An examination of 750 museum specimens of the Southern Leopard Frog (Lithobates sphenocephalus) collected during 1938-1989 from eastern Virginia (USA) provided comparative life-history data from the northeastern portion of this species geographic range. Individuals were collected in all months except December. Testis size was largest and incidence of gravid females was highest during fall and spring. In both sexes, fat storage was lowest during late-winter-spring, which is indicative of increased activity and commencement of breeding. Incidence of food in stomachs was lowest in late winter and relatively high thereafter, especially in males. Geographic trends in five lifehistory traits were corroborated for the Southern Leopard Frog in this study, including breeding season, egg size, mean adult body size, sexual size dimorphism, and larval metamorphosis season. In response to hotter summers and milder winters, as predicted to occur with climate change, the reproductive characteristics for this species in Virginia will likely shift to resemble contemporary reproductive patterns of southern populations.

Key words: anuran breeding; climate change; clutch size; geographic variation; life history; Southern Leopard Frog.

The Southern Leopard Frog, Lithobates sphenocephalus (Cope, 1886), is a geographically widespread North American ranid that occurs throughout much of the southeastern United States, extending as far west as eastern Kansas and eastern Texas (Conant \& Collins, 1998). The extreme northeastern edge of its geographic range is found in southeastern Pennsylvania,
New Jersey, and extreme southeastern New York (Butterfield et al., 2005). In Virginia, this species is found along the eastern portion of the Commonwealth and is largely absent from the higher elevations of the Appalachian Mountains in the West (DodD, 2013). Although life-history traits for this species are generally well-studied (e.g. Trauth, 1989; Meshaka \& Marshall, 
2011; Mitchell \& Pague, 2014), baseline data from populations in the northern parts of its distribution are lacking.

The Southern Leopard Frog exhibits geographic trends in five life-history traits, which are typical for a temperate-latitude amphibian species. In general, breeding season of this species is longest in southern populations (MeshaKa \& Layne, 2015). Egg-laying was found to be essentially continuous in Florida and Louisiana, with fall and spring peaks, especially during December to February, whereas breeding occurred during fall and / or spring and also in winter if temperatures were not too low elsewhere in its range (Meshaka \& LAYNE, 2015). In central Virginia, breeding was reported during late February or March-April of a two-year study and in September during one of the study years (Mitchell, 1986). Congeners of the Southern Leopard Frog in the Lithobates pipiens complex were found to have produced larger eggs in populations occurring in the northern extent of their range (MOoRE, 1949). Mean adult body size of the Southern Leopard Frog was found to be smaller in northern populations and the degree of sexual size dimorphism (SSD) was also found to be greater at higher latitudes (Meshaka \& Layne, 2015). Larval transformation for the Southern Leopard Frog was found to have occurred within a similarly narrow season along the northern edges of its geographic range and longest in the South (Meshaka \& Layne, 2015). In central Virginia, larval metamorphosis generally occurred during June-early-July, approximately three months after breeding, or during 17 May-23 June following September breeding (Mitchell, 1986). Similarly, larval metamorphosis occurred during mid-June-July in Arkansas (Trauth et al., 2004), mid-June-late July in Missouri, and June-early-July in Illinois (Sмітн, 1961). However, farther south in the Okefenokee Swamp of southeastern Georgia, larval metamorphosis was reported during April -October and was thought to have probably been continuous (Wright, 1931). In southern Florida, larval metamorphosis occurred throughout the year (MEshaKa \& Layne, 2015).

For this study, we used a large series of museum specimens from eastern Virginia to test the geographic patterns associated with five life-history traits, including breeding season, egg size, adult body size, sexual size dimorphism, and larval metamorphosis season near the northeastern edge of the Southern Leopard Frog's geographic range. We also provide data on clutch characteristics, and age and body size at sexual maturity that we compare to those of other populations of the Southern Leopard Frog. Lastly, we speculate on future deviations in some life-history characteristics as a biological response to projected global climate changes (e.g. BLAustein et al., 2001), particularly warming trends in northern latitudes and impacts of sea level changes on coastal regions in the eastern United States.

\section{Materials and Methods}

We examined 750 Virginia specimens of the Southern Leopard Frog, collected during 1938-1989, from the holdings of the Carnegie Museum of Natural History in Pittsburgh, Pennsylvania. The specimens were collected during a 51-year period from 22 counties along the eastern region 
VIRGINIA COUNTIES AND INDEPENDENT CITIES *

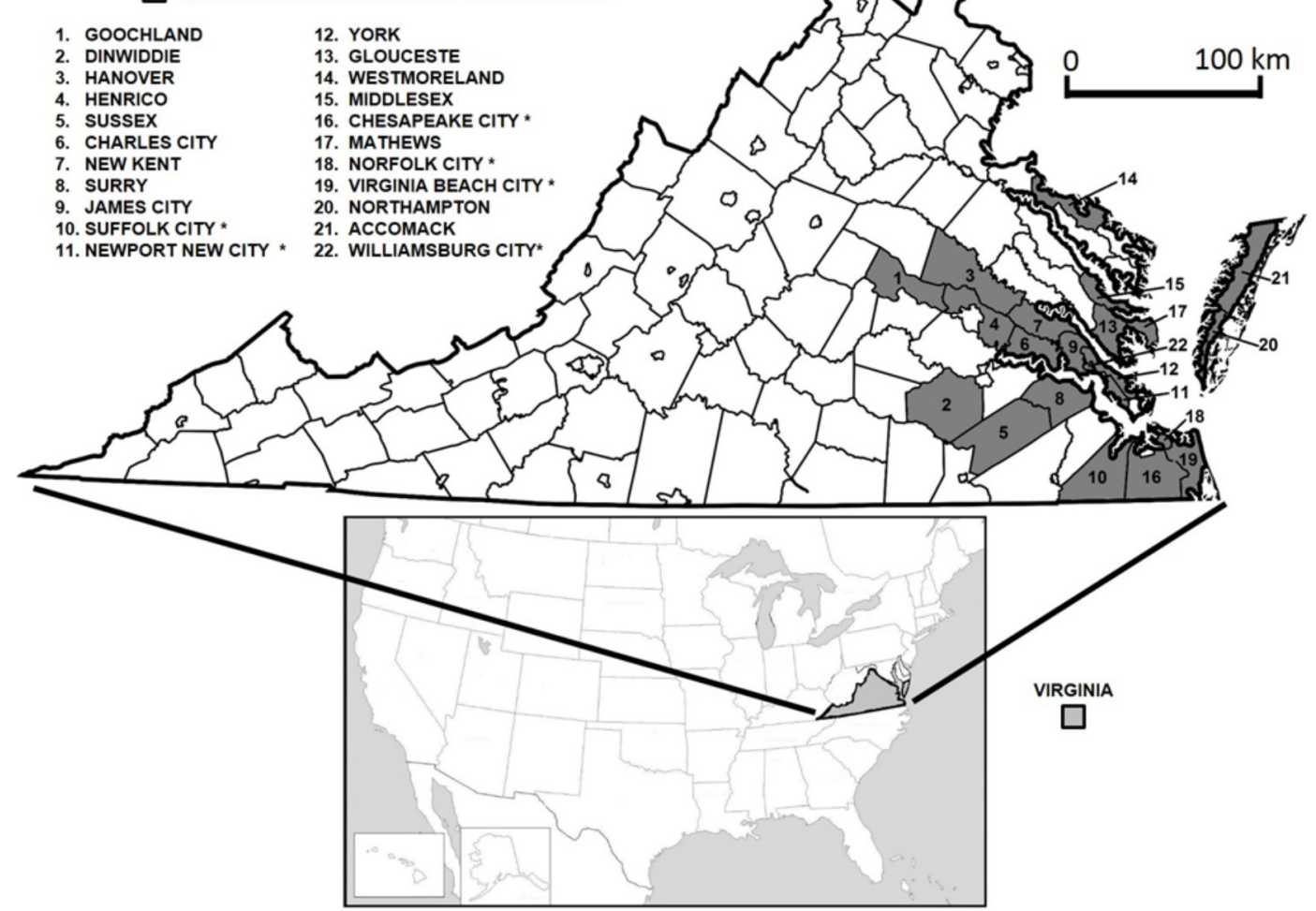

Figure 1: Map of Virginia (USA) showing the counties of origin for the 750 museum specimens of the Southern Leopard Frog (Lithobates sphenocephalus) examined in this study, which are archived at the Carnegie Museum of Natural History in Pittsburgh, Pennsylvania, USA.

of Virginia (Fig. 1). Frog specimens representing all major life-history stages were examined, including adults, juveniles, newly metamorphosed juveniles, tadpoles, and egg masses. Of note was the regional emphasis of specimens originating from coastal areas, and in particular, Virginia's portion of the Delmarva Peninsula, a biogeographically and physiographically distinct maritime province represented in our sample by Accomack and Northampton Counties (Fig. 1).

Body lengths of all frog specimens were measured in snout-vent length (SVL) to the nearest $0.1 \mathrm{~mm}$ using vernier cali- pers. To reduce some of the effect derived from preservation artifacts (LEE, 1982), all measurement data were recorded by the first author. Newly metamorphosed juveniles were distinguished from tadpoles by the presence of forelimbs (Gosner stage 42) (Gosner, 1960) and distinguished from juveniles by the presence of a tail. Sexual maturity in males was determined by the presence of enlarged testes and thumbs (Meshaka, 2001). Length and width of the left testis as a percent of the body size (SVL) was used to provide a measure of male fertility (Meshaka, 2001). Incidence of males with enlarged thumbs also served 


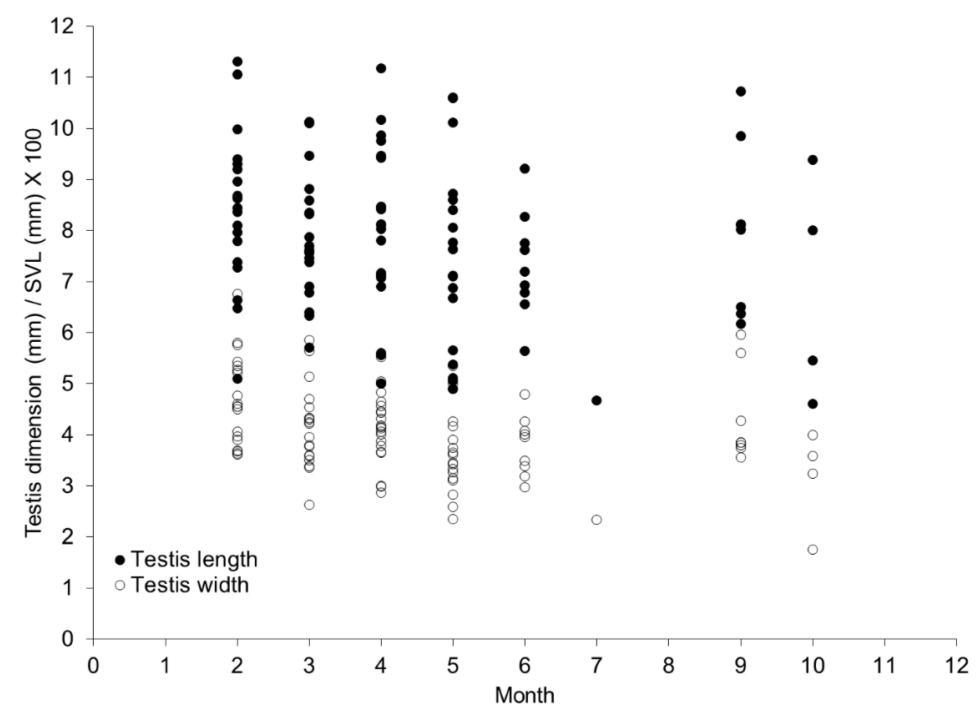

Figure 2: Monthly distribution of testis length and width as a percentage of body size, in mm of snoutvent length (SVL), in 100 male Southern Leopard Frogs (Lithobates sphenocephalus) from eastern Virginia (USA).

as a measure of seasonal patterns of fertility. Sexually mature females were associated with one of four ovarian stages as per Meshaka (2001). In brief, for the first ovarian stage, oviducts were thin and uncoiled, and the ovaries were somewhat opaque. In the second ovarian stage, the oviducts were larger and more coiled, and the ovaries contained some pigmented oocytes. In the third ovarian stage, oviducts were thick and heavily coiled, and the ovaries were in various stages of clutch development. In the fourth ovarian stage, oviducts were thick and heavily coiled, and the ovaries were full of polarized ova with few non-polarized ova, signifying a fully developed clutch and gravid female.

A random subset of 11 gravid females was examined for clutch characteristics. Entire clutches were removed from the body cavity and gently patted with a paper towel to remove excess moisture. The entire clutch was massed on an electronic scale to the nearest $0.1 \mathrm{~g}$. A counted subset of ova was massed and that mass was extrapolated to the weight of the entire clutch as an estimate of clutch size. From each of these 11 clutches, the diameters of 10 randomly chosen ova were measured using an ocular micrometer; the largest ovum was used in comparative relationships with clutch size and female body size. The SSD was calculated by dividing the mean adult body size of males by that of females.

Fat body development was scored as absent, intermediate in volume in the body cavity, to extensive development that extended cranially within the body cavity. The latter amount was used as an estimation of the monthly incidence of extensive fat relative to all males and females examined in each month. The presence of food in the stomach was used as an approximation of the monthly frequency of individuals that had been feeding for all males or females examined from each month.

All quantitative graphics were produced and statistical analyses conducted in Excel 2007 (Microsoft Inc., Redmond, Washington, USA). Means in our analyses are followed by \pm 1 standard deviation. 

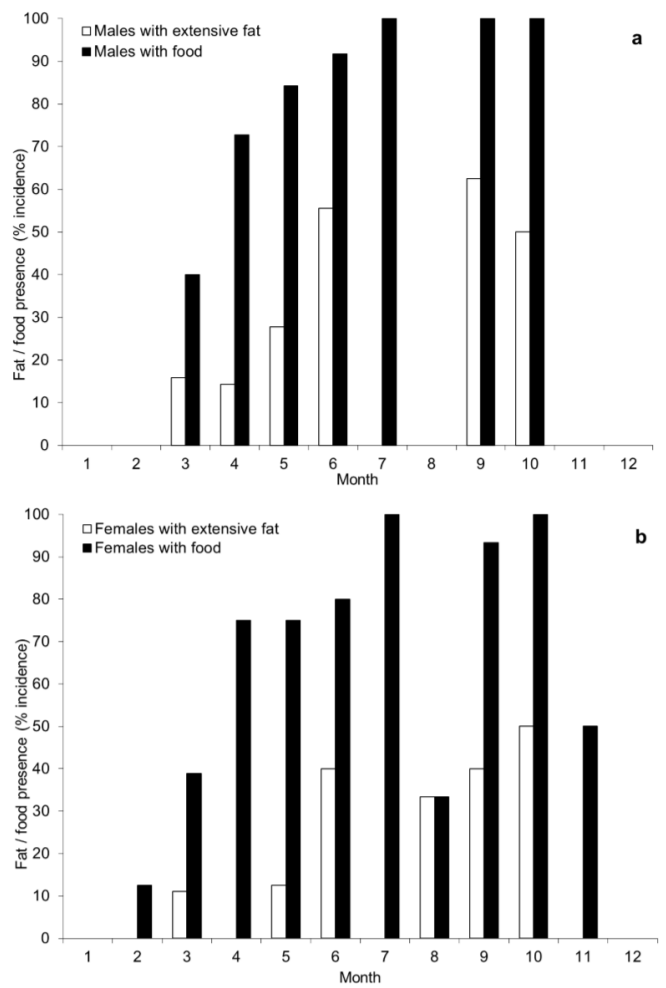

Figure 3: Monthly frequency of extensive fat in the body cavity and the presence of food ( $N$ = 99) in the stomach of $(\mathrm{A})$ male $(\mathrm{N}=107)$ and (B) female $(\mathrm{N}=100)$ Southern Leopard Frogs (Lithobates sphenocephalus) from eastern Virginia (USA).

Sample means were compared using twosample t-tests (two-tailed) with unequal variances; ANOVA F-tests were used to compare variances between egg diameter samples; and Pearson Correlation for statistical significance tests were used to examine relationships between selected variables. Statistical significance was recognized at a $P$-value $<0.05$. Data in our analyses met parametric assumptions and therefore did not require logtransformation or any other mathematical adjustment (ZAR, 1996). The Virginia county map was produced using ArcGIS ver- sion 10.3 (ESRI, 2014). The map was then embedded within a digital art board using Adobe Illustrator (Version CS6; Adobe Systems Inc., San Jose, California, USA) and prepared into the final figure.

\section{Results}

\section{Male reproduction}

The monthly distribution of testis length and width as a percentage of SVL was indicative of a steady decrease in testis dimensions beginning in late winter and reaching minimal sizes by early summer (Fig. 2). Testicular recrudescence was evident in September and October samples. All males examined in this study possessed enlarged thumbs. The monthly percentage of males with extensive fat development during March-October was lowest in March and April, and rapidly increased thereafter (Fig. 3). The monthly percentage of males containing food was lowest in March and increased steadily thereafter, peaking from July through October (Fig. 3).

\section{Female reproduction}

Gravid females (ovarian stage 4) were present in each month during JanuaryNovember except July (Fig. 4). Most gravid females were found during SeptemberMarch. The months having the lowest frequency of gravid females coincided with those having spent females (ovarian stage 1) (Fig. 4), indicating an end to oviposition by early summer and a late-summer-fall commencement of egg production for reproduction in the following late-winter. To that end, egg masses were collected on 20 February 1986, 14 March 1986, 8 March 1987, and 14 March 1987. 

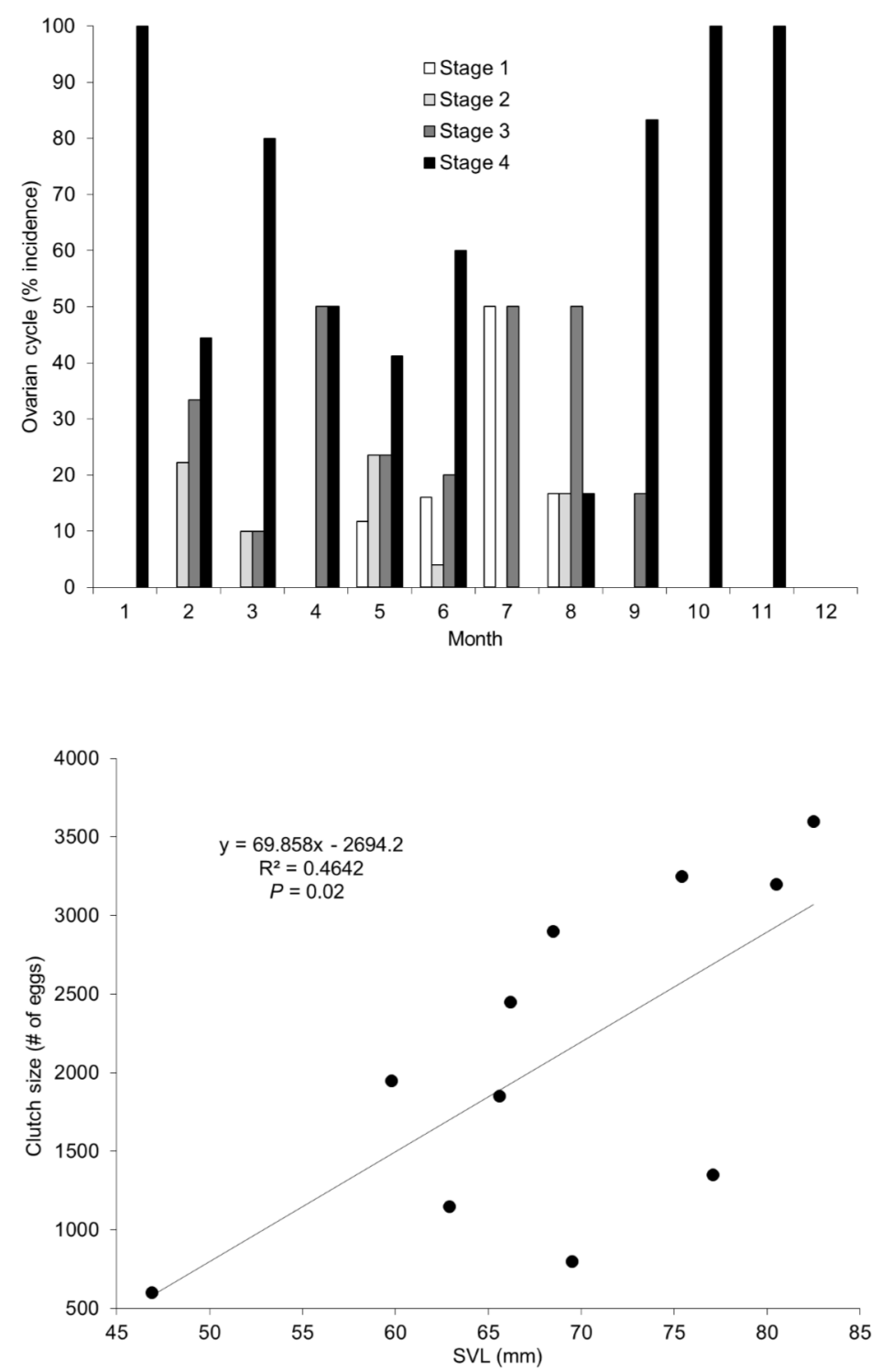

Figure 4: Monthly ovarian cycle of 108 female Southern Leopard Frogs (Lithobates sphenocephalus) from eastern Virginia (USA). Stage 1: thin uncoiled oviducts / ovaries opaque, Stage 2: large moderate coiled oviducts / ovaries with oocytes, Stage 3: thick heavily coiled oviducts / ovaries with multi stage oocytes, Stage 4: thick heavily coiled oviducts / most or all ova polarized.

Figure 5: The relationship between clutch size and female body size, expressed as snout-vent length (SVL), in 11 female Southern Leopard Frogs (Lithobates sphenocephalus) from eastern Virginia (USA).

\section{Clutch characteristics and fat cycles}

Eleven females (mean SVL $=68.6 \pm 10.3$ $\mathrm{mm}$; range $=46.9-82.5$ ) produced a mean estimated clutch size of $2100 \pm 1050.5$ eggs (range $=600-3600)$. The relationship between clutch size and female body size was positive and statistically significant (Pearson Correlation, $\mathrm{R}^{2}=0.46, P=0.02$ )
(Fig. 5). The mean ovum diameter of 110 ova from 11 gravid females measured 1.44 $\pm 0.173 \mathrm{~mm}$ (range $=1.1-1.8$ ). The relationships, however, between mean ovum size and female body size or between mean ovum diameter and clutch size were not statistically significant (Pearson Correlation, $P>0.05)$. 


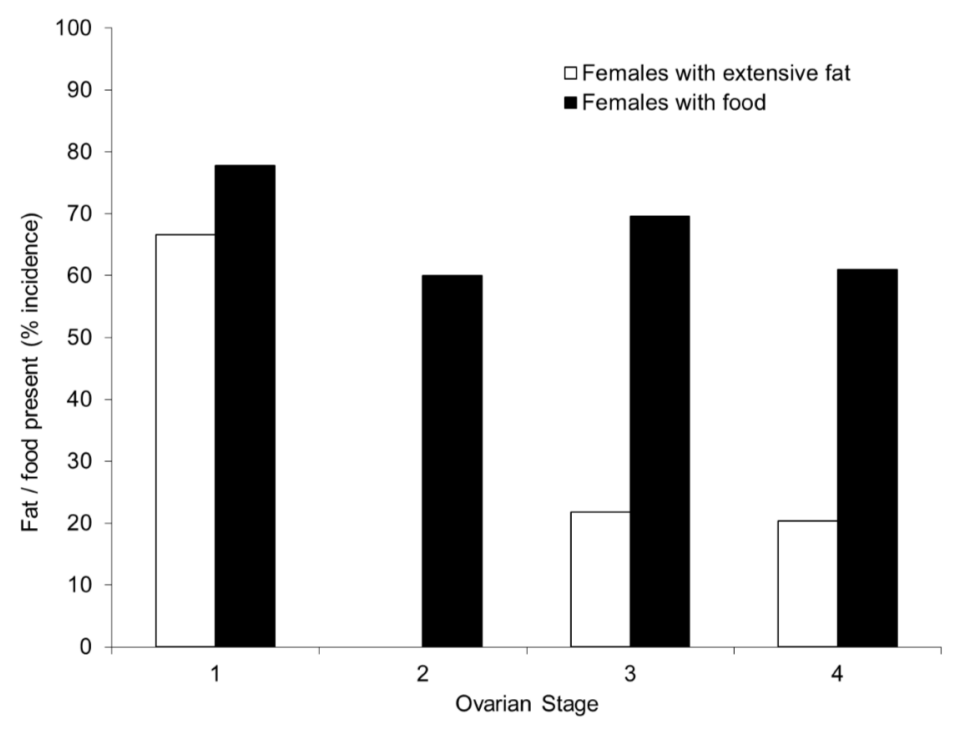

Figure 6: Frequency of extensive fat and the presence of food in each of the four ovarian stages of 101 female Southern Leopard Frogs (Lithobates sphenocephalus) from eastern Virginia (USA). Stage 1: thin uncoiled oviducts / ovaries opaque, Stage 2: large moderate coiled oviducts / ovaries with oocytes, Stage 3: thick heavily coiled oviducts / ovaries with multi stage oocytes, Stage 4: thick heavily coiled oviducts / most or all ova polarized.
The highest incidence of extensive fat among sexually mature females was found in $67 \%$ of spent females (ovarian stage 1) (Fig. 6). No females beginning oogenesis (ovarian stage 2) contained extensive fat, and only $20 \%$ of nearly gravid (ovarian stage 3 ) and gravid (ovarian stage 4) females contained extensive fat (Fig. 6), suggestive of fat depletion concomitant with clutch production. The frequency of females containing food varied between 60 and $78 \%$ among ovarian stages, the highest value occurring in spent females (Fig. 6), which represented the segment of the female population having the maximum coelomic cavity space to hold food and the greatest immediate need for food. The monthly incidence of females containing extensive fat was lowest in March and May, overlapping with the egg-laying season, followed by an increase in June and a steady increase until a peak in the fall (Fig. $3)$. With the exception of August, the lowest incidences of food occurred early and late in the active season (Fig. 3), when fe- males would be gravid, with little room for food, and cold, with little need for food.

\section{Growth and sexual maturity}

The smallest juveniles were captured on 27 September 1969 (20.5 mm SVL), 19 July 1952 (21.5 mm SVL), and 26 July 1989 (21.6, $21.9 \mathrm{~mm}$ SVL) (Fig. 7). The smallest juveniles collected before July, two measuring $27.7 \mathrm{~mm}$ SVL, were collected on 21 June 1989. Three newly metamorphosed individuals, measuring 25.3, 28.3, and 28.7 mm SVL, were collected on 26 July 1989.

The monthly distribution of body sizes (Fig. 7) suggests that growth rate is approximately $3 \mathrm{~mm} /$ month, and that males reached a minimum adult body size of 42.2 $\mathrm{mm}$ SVL within three or four months of metamorphosis or early the following spring-early-summer at eight or nine months of post-metamorphic age. Males reached their mean body size of $52.9 \pm 5.8$ $\mathrm{mm}$ SVL (range $=42.2-69.5 ; \mathrm{N}=109$ ) as early as approximately 10-11 months of post-metamorphic age (Fig. 7). 


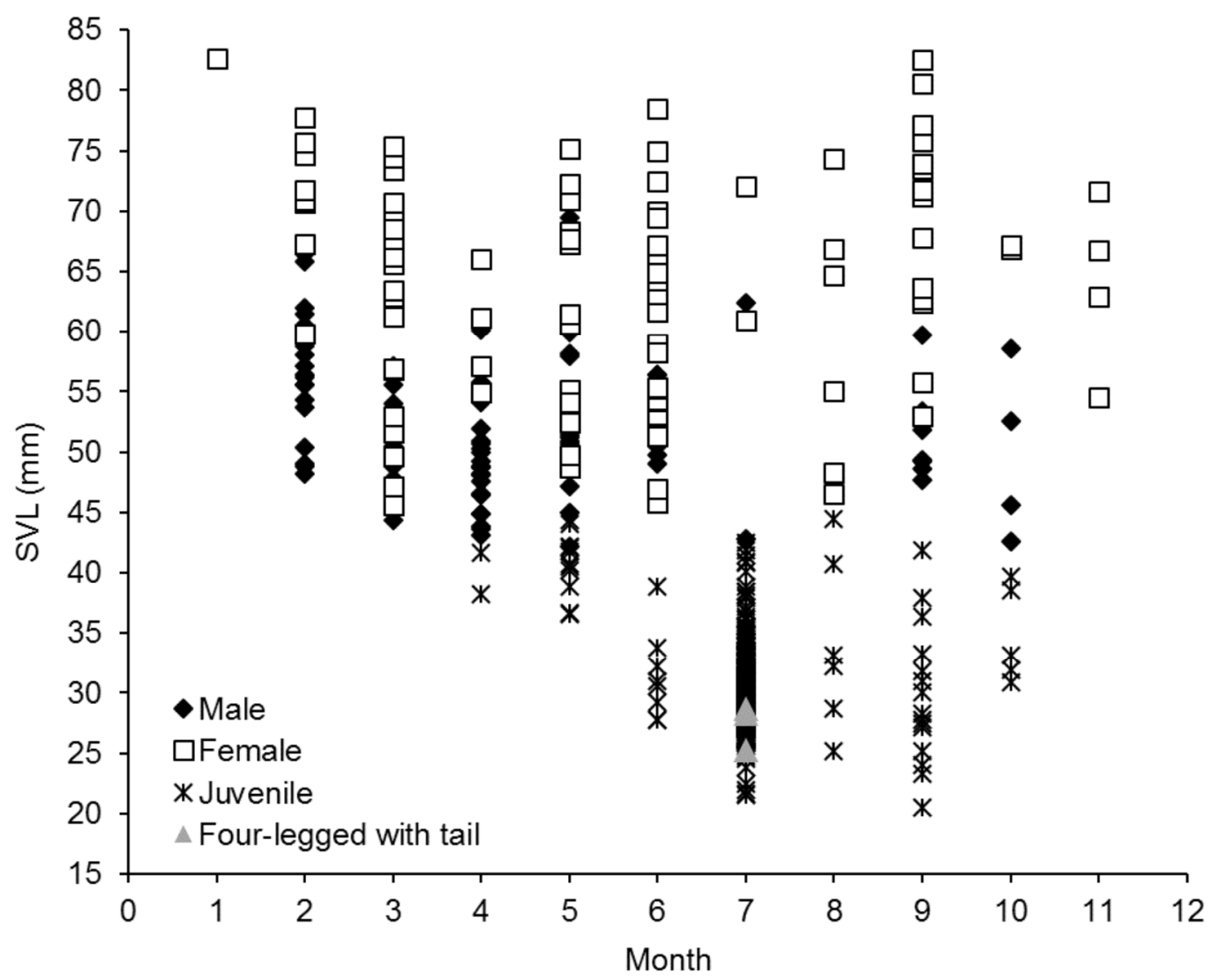

Figure 7: Monthly distribution of body sizes, expressed as snout-vent length (SVL), of males $(\mathrm{N}=$ $109)$, females $(\mathrm{N}=108)$, juveniles $(\mathrm{N}=530)$, and newly metamorphosed individuals $(\mathrm{N}=3)$ of the Southern Leopard Frog (Lithobates sphenocephalus) from eastern Virginia (USA).

Mean adult body size of sexually mature females was $63.8 \pm 9.2 \mathrm{~mm}$ SVL (range =45.6-82.6; $\mathrm{N}=108)$. The smallest females with yolking eggs measured 47.2 (ovarian stage 2) and $45.6 \mathrm{~mm}$ SVL (ovarian stage $3)$. The smallest reproductively quiescent female (ovarian stage 1) measured 45.8 $\mathrm{mm}$ SVL, and the smallest gravid female (ovarian stage 4) measured $46.9 \mathrm{~mm}$ SVL. Females would likely reach sexual maturity no earlier than at eight months after metamorphosis and mean adult body size at 16 months.

The mean body size, but not the vari- ance (F-test, $P>0.05$ ), of 66 gravid females $($ mean $=65.4 \pm 8.8 \mathrm{~mm}$ SVL; range $=46.9$ 82.6) was significantly larger $(\mathrm{t}=2.340, \mathrm{df}=$ $106, P=0.02)$ than that of non-gravid counterparts $($ mean $=61.2 \pm 9.3 \mathrm{~mm} \mathrm{SVL}$; range = 45.6-77.7; $\mathrm{N}=42$ ). Statistical significance was found in the differences in the variance $(\mathrm{F}=0.397, P<0.001)$ and mean $(\mathrm{t}=$ 10.465, df $=180, P<0.001)$ between adult body sizes of males and females.

\section{Discussion}

The reproductive season of the Southern Leopard Frog is known to vary geo- 
graphically, with northern populations breeding generally in the spring and southern populations breeding potentially at any time, especially in the fall and again in the spring (Butterfield et al., 2005). Cold winters in the North and hot summers in the South associated with thresholds of contemporary mean high and low monthly temperatures interrupt breeding in otherwise fertile individuals of the Southern Leopard Frog (Meshaka \& Layne, 2015). The effects on present-day anuran breeding activities imposed by climate change, some of which could lead to dramatic deviations in future population structure (Blaustein et al., 2001) and increased extinction risk (UrbaN, 2015), highlight the importance of long-term life-history data from populations across the whole distribution of a species for understanding the potential impacts. Data sets from regions representing the geographic edges of a species distribution are especially important to more fully understand how to manage the anuran populations most vulnerable to changes in climate (BLAUSTEIN $e t$ al., 2010).

The geographic range of the Southern Leopard Frog extends from the Florida Keys and southeastern Texas north to Missouri and Long Island, New York, exclusive of much of the higher elevations in the Appalachian Mountains (ConAnt \& ColLINS, 1998). In Virginia, the Southern Leopard Frog is restricted to the eastern portion of the Commonwealth (DodD, 2013), thereby placing the region of our study near the northeastern edge of its distribution (see Fig. 1). Our data revealed that the Southern Leopard Frog was gravid throughout much of the year in Virginia, especially in the colder months. The monthly distribution of incidence for gravid females, newly metamorphosed individuals, and young-of -the-year was suggestive of primarily winter-early-summer breeding; however, fall breeding could not be ruled out. Corroboratively, during a two-year study at a single site in Chesterfield County, central Virginia, the Southern Leopard Frog was reported to have bred during February-April in each season and in September during one season (MitchelL, 1986). In Greensville County, southern Virginia, males of this species were reported to be calling as late as the end of May (Hofrman \& МiтcHeLL, 1996). To the north in Pennsylvania, breeding for this species was reported in April (Hulse et al., 2001). At similar latitudes westward, Missouri populations were reported to breed during Marchearly-May and occasionally in autumn (Johnson, 1987). In Illinois, breeding was reported during early-March-April (Sмітн, 1961). In Indiana, spring breeding was reported and occasional calling recorded in the fall (Minton, 2001). However, Stiles \& LANNOO (2015) confirmed fall breeding over a three-year period, which they suggested to have been a possible climate change-related shift from the typical breeding season along the northern edge of its geographic range. Farther south, the Southern Leopard Frog was reported to breed during February-April in Maryland and the District of Columbia (Harris, 1975). In Delmarva, breeding was reported during February-April (White \& White, 2002). In Arkansas, the Southern Leopard Frog bred during late-winter-early-spring and again briefly in the fall (MCCallum et al., 2004; Trauth et al., 2004). 
In the extreme southeastern United States, breeding for this species was found to be possible throughout the year, even if distinctly peaking in colder months (e.g. Meshaka \& Layne, 2015). For example, early-fall (September-October) or fall-latewinter (November-February or March) breeding was considered typical in South Carolina (CALDwell, 1986). In southern Louisiana, breeding took place year-round, but especially during December-February (Dundee \& Rossman, 1989). In Florida, calling was heard generally throughout the year but peak activity occurred during winter-early-spring (Ashton \& Ashton, 1988). In central Florida, eggs were found during September-May (BANCroft et al., 1983), and in central and southern Florida, breeding was more or less continuous with distinct fall-spring peaks in calling (P.R. Delis, unpublished data; Meshaka \& LAYNe, 2015).

Clutch size was proffered to vary geographically (McCallum et al., 2004). A hypothesis most accurately tested by controlling for which clutch of potentially multiple clutches (e.g. McCallum et al., 2004) would be used in comparisons as well as discerning between ovarian clutch size and oviposited clutch size (see below). Mean clutch size from our sample (2100) was within the range for this species of approximately 1500-4000 eggs: mean $=1766.1$ oviposited eggs in Virginia (Mitchell \& PAGUE, 2014), 2958.7 ovarian and 2106.5 oviposited eggs (Trauth, 1989) and 1825 oviposited eggs (McCallum et al., 2004) in Arkansas, 1585.4 ovarian eggs in northern Louisiana (Meshaka \& Marshall, 2011), and 3795 ovarian eggs in southern Florida (Meshaka \& Layne, 2015).
Moore (1949) noted a geographic gradient in ovum size in the L. pipiens complex, the largest of which were from populations in the north. Mean ovum size of our sample $(1.44 \mathrm{~mm})$ was similar to that of southern Florida $($ mean $=1.36 \mathrm{~mm}$ ). Mean ovum size was larger in frogs from Louisiana $(1.60 \mathrm{~mm})$ (Moore, 1949), and was largest among conspecifics from Arkansas $(1.76 \mathrm{~mm})$ (Trauth, 1989), as well as in the Northern Leopard Frog, L. pipiens (Schreber, 1782), in Pennsylvania (1.77 $\mathrm{mm}$ ) (Meshaka et al., 2011), Wisconsin (1.76 $\mathrm{mm}$ ), and Vermont (1.77 $\mathrm{mm}$ ) (Moore, 1949). Among Southern Leopard Frogs in northeastern Arkansas, McCallum et al. (2004) noted larger egg size in fall clutches than in spring clutches, corroborating the notion that fall breeding was secondary to late-winter-spring breeding. Similar to populations of southern Florida (Meshaka \& LAYNE, 2015), our Virginia sample exhibited a positive relationship between clutch size and body size, but not in ovum size. It remains to be seen the extent to which these values would be affected by the seasonal timing of the clutch.

Two to three months of larval growth were estimated for our sample from Virginia. The same was true in much of the South (Meshaka \& Layne, 2015). Likewise, in central Virginia, MitcheLl (1986) reported a larval period of approximately three months, unless breeding took place in September, in which case the larval period extended to eight months (i.e. overwintering). Nevertheless, the extent of time in which larval metamorphosis occurs in the Southern Leopard Frog follows a geographic gradient (e.g. Meshaka \& Layne, 2015). Our data fit the pattern of a shorter 
metamorphosis (May-September) season in the North: May-June in Virginia (Mitchell, 1986), April-October in the Okefenokee Swamp of southeastern Georgia (Wright, 1931), mostly May-October in central Florida (BANCROFT et al., 1983), and year-round in central and southern Florida (P.R. Delis, unpublished data; Meshaka \& LAYNe, 2015). Moreover, Hoffman \& Mitchell (1996) reported that a large number of recently metamorphosed Southern Leopard Frogs were found in pitfall traps during 25 May-30 June in 1994 from Clarksville, southern Virginia.

We found that body size at metamorphosis in Virginia, although variable, was within the range reported for this species (e.g. Meshaka \& Layne, 2015). The monthly distribution of juvenile body sizes from our Virginia sample suggests that there should be a May juvenile body size that was lower than the 27.7-33.8 $\mathrm{mm}$ SVL of June and the largest July newly metamorphosed individuals. If this is so, then eggs having been laid in late February through early March could have produced May and June newly metamorphosed individuals three months later. The smallest juvenile collected at the end of September, in turn, would presumably have come from a clutch laid in June-the tail end of what was primarily, but not exclusively, a latewinter-spring egg-laying season.

Small mean adult body sizes in our Virginia sample corroborated findings of smaller mean adult body sizes of males and females of the Southern Leopard Frog in regions where it co-occurred with potential competitors (MeshaKa \& Layne, 2015): 61.1 and $76.0 \mathrm{~mm}$, respectively, in Everglades National Park, Florida
(Meshaka \& Layne, 2015), 65.5 and 63.8 $\mathrm{mm}$, respectively, in Lake Placid, Florida (Meshaka \& Layne, 2015), 55.8 and 63.7 $\mathrm{mm}$, respectively, in Pennsylvania (Hulse et al., 2001), and 57.1 and $63.2 \mathrm{~mm}$, respectively, in Indiana (Minton, 2001). Likewise, the maximum body size of each sex was larger in southern Florida (Meshaka \& LAYNE, 2015) than in the north, such as populations from Pennsylvania (Hulse et al., 2001), Indiana (Minton, 2001), and this study.

Sexual maturity in male Southern Leopard Frogs from this study could be reached in three to six months after larval transformation, thereby resulting in breeding for the first time the following latewinter or spring at less than one year of age post-transformation. The monthly distribution of female body sizes from our Virginia sample indicated a minimum body size of sexual maturity of at least 46 $\mathrm{mm}$ SVL at approximately nine to 10 months of post-metamorphic age, if uninterrupted by winter. Consequently, females would be able to breed in February at approximately 10 months of postmetamorphic age. Females that transformed late in the season (e.g. September) might not be sexually mature until nine months later around June, when they might or might not have bred in the fall. If interrupted by winter, mean adult body size of sexually mature females could have been reached at ca. 16 months of postmetamorphic age. In southern Florida, sexual maturity was reached in approximately four to five months after transformation (Meshaka \& Layne 2015), whereas first breeding occurred at one year in the Okefenokee Swamp of Georgia (WRIGHT, 1931). 
We found that the minimum body size at sexual maturity was smaller in males than females from Virginia and this was consistent with findings from elsewhere (e.g. Hulse et al., 2001; Minton, 2001; MeSHAKA \& LAYNe, 2015). Among these aforementioned studies, the smallest sexually mature adults were found in our study and ranged 42.2-46 $\mathrm{mm} \mathrm{SVL}$ and 45.6-52.0 $\mathrm{mm}$ SVL, for males and females, respectively. For southern Florida females, the minimum value for Everglades National Park was $52.0 \mathrm{~mm}$, whereas a $57 \mathrm{~mm} \mathrm{SVL}$ minimum body size was found from Lake Placid (Meshaka \& Layne, 2015). The SSD value among Virginia adults (0.83) was more similar to values from two samples in southern Florida $(0.80,0.82)$ (MeshaKA \& Layne, 2015) than it was to those of Pennsylvania (0.88) (Hulse et al., 2001) and Indiana (0.90) (Minton, 2001), suggestive of a slightly greater SSD from more southernlatitude populations.

\section{Conclusions}

In summary, our findings corroborated geographic trends in five life-history traits for the Southern Leopard Frog. For other traits, geography was interpreted to have played a diminished role, if any. The geographic trends we found for this species conformed to the general patterns of amphibian life-history traits in temperatelatitudes (Morrison \& Hero, 2003). The northerly pattern we observed in breeding season for this species provides predictive power relating to future population responses, not only spatially, but also temporally. Consequently, and given current concerns with regard to amphibian declines linked to global warming (e.g. STU-
ART et al., 2004), we wish to call attention to two, in our opinion, significant points. First, the Southern Leopard Frog has been historically reported from the two eastern shore counties of Virginia, which form the southern extent of the Delmarva Peninsula (Northampton and Accomack) (Conant, 1945; Gibbons \& CoKer, 1978; Conant et al., 1990; Roble et al., 2000; this study). The Delmarva Peninsula represents the northern portion of the Middle Atlantic Coastal Plains ecoregion, a highly threatened area that harbors a diverse biotic assemblage (RAY, 1991) that has been recently elevated to a Global Biodiversity Hotspot as the North American Coastal Plain (Noss et al., 2015). The biodiversity of this coastal ecoregion is particularly vulnerable to threats imposed by global climate change, especially increases in the frequency and severity of coastal storms (HоRTON et al., 2015), and rising sea levels (Nicholls \& Cazenave, 2010). These distinctly maritime threats have the potential to accelerate extirpation rates of coastal populations compared to their mainland counterparts, compelling an urgency for investigations. Unfortunately, the amphibian fauna of the peninsula's southern point has been only cursorily examined (e.g. Mitchell, 2002). Even though Virginia has a distinguished history of herpetological research (see Mitchell, 2013), our results represent one of the most extensive studies on Southern Leopard Frog populations from this coastal region. We maintain that this disjunct peninsula possesses high biogeographical value for amphibians and recommend continued monitoring and collection efforts that will greatly contribute to our understanding of how to manage 
coastal anuran populations faced with arguably the most formidable threats associated with climate change. Second, with regard to mainland Virginia, the contemporary breeding season of these populations-as beginning to be observed elsewhere (e.g. Stiles \& LANNoo, 2015) - is unlikely to remain stable in the face of climate change, the effects of which will trend towards hotter summers and milder winters (GARCIA et al., 2014 and citations therein). Considering these putative climatic changes in relation to the thermal thresholds associated with anuran breeding seasons, a dramatic shift by this species to a reproductive season resembling that of current populations in the extreme southeastern United States is a reasonable expectation and testable hypothesis. Furthermore, anuran populations at the margins of a species' range represent, often, the extremes in geographic variation of life -history traits, and these data will be fundamental to accurate modelling of anuran responses to environmental change (e.g. Orizaola \& Laurila, 2016). To that end, now equipped with life-history data from a large sample at this species northerly range limit, researchers can more reliably investigate the relative influence of climate change on the reproductive phenology and life history in the Southern Leopard Frog across its range.

\section{Acknowledgement}

A debt of gratitude goes to Stephen P. Rogers, Collections Manager at the Carnegie Museum of Natural History, for the loan of specimens and to staff of the Powdermill Nature Reserve who kindly transported specimens to and from the muse- um. We also thank Jaclyn M. Adams for help constructing the map in Figure 1.

\section{REFERENCES}

Ashton, R.E. \& Ashton, P.S. (1988). Handbook of Reptiles and Amphibians of Florida Part Three: The Amphibians, $2^{\text {nd }}$ ed. Windward Publishing, Miami, Florida, USA.

Bancroft, G.T.; Godley, J.S.; Gross, D.T.; RoJAS, N.N. \& SutPhen, D.A. (1983). Large-Scale Operation Management Test of Use of the White Amur for Control of Problem Aquatic Plants. The Herpetofauna of Lake Conway: Species Accounts. Final Report. Series: Miscellaneous Paper, Vol. A-83-5. U.S. Army Engineer Waterways Experimental Station, Vicksburg, Mississippi, USA.

Blaustein, A.R.; Belden, L.K.; Olson, D.H.; Green, D.M.; Root, T.L. \& Kiesecker, J.M. (2001). Amphibian breeding and climate change. Conservation Biology 15: 1804-1809.

Blaustein, A.R.; Walls, S.C.; Bancroft, B.A.; Lawler, J.J.; Searle, C.L. \& Gervasi, S.S. (2010). Direct and indirect effects of climate change on amphibian populations. Diversity 2: 281-313.

Butterfield, B.P.; Lannoo, M.J. \& Nanjappa, P. (2005). Rana sphenocephala Cope, 1886: Southern leopard frog, In M.J. Lannoo (ed.) Amphibian Declines: The Conservation Status of United States Species, University of California Press, Berkeley, California, USA, pp. 586587.

Caldwell, J.P. (1986). Selection of the egg deposition sites: A seasonal shift in the southern leopard frog, Rana sphenocephala. Copeia 1986: 249-253.

Conant, R. (1945). An Annotated Check List of the Amphibians and Reptiles of the Del-Mar-Va Peninsula. The Society of Natural History of Delaware, Wilmington, Delaware, USA.

Conant, R. \& Collins, J.T. (1998). Reptiles and Amphibians of Eastern/Central North America, $3^{\text {rd }}$ ed. Houghton Mifflin Company, New York, USA. 
Conant, R.; Mitchell, J.C. \& Pague, C.A. (1990). Herpetofauna of the Virginia barrier islands. Virginia Journal of Science 41: 364380.

Dodd, C.K., JR. (2013). Frogs of the United States and Canada. The John Hopkins University Press, Baltimore, Maryland, USA.

Dundee, H.A. \& Rossman, D.A. (1989). The Amphibians and Reptiles of Louisiana. Louisiana State University Press, Baton Rouge, Louisiana, USA.

ESRI (2014). ArcGIS: Release 10.3 Edition. Environmental Systems Research Institute (ESRI), Inc., Redlands, California, USA.

Garcia, R.A.; Cabeza, M.; Rahbek, C. \& Araújo, M.B. (2014). Multiple dimensions of climate change and their implications for biodiversity. Science 344: 1247579.

Gibbons, J.W. \& Coker, J.W. (1978). Herpetofaunal colonization patterns of Atlantic Coast barrier islands. American Midland Naturalist 99: 219-233.

Gosner, K.L. (1960). A simplified table for staging anuran embryos and larvae with notes on identification. Herpetologica 16: 183-190.

HARris, H.S., JR. (1975). Distributional survey (Amphibia/Reptilia): Maryland and the District of Columbia. Bulletin of the Maryland Herpetological Society 11: 73-167.

Hoffman, R.L. \& Mitchell, J.C. (1996). Records of anurans from Greensville County, Virginia. Banisteria 8: 29-36.

Horton, R.; Little, C.; Gornitz, V.; Bader, D. \& Oppenheimer, M. (2015). New York City panel on climate change 2015 report chapter 2: Sea level rise and coastal storms. Annals of the New York Academy of Sciences 1336: 3644.

Hulse, A.C.; McCoy, C.J. \& Censky, E.J. (2001). Amphibians and Reptiles of Pennsylvania and the Northeast. Cornell University Press, Ithaca, New York, USA.

Johnson, T.R. (1987). The Amphibians and Reptiles of Missouri. Missouri Department of Conservation, Jefferson City, Missouri, USA.

LEE, J.C. (1982). Accuracy and precision in anu- ran morphometrics: Artifacts of preservation. Systematic Biology 31: 266-281.

McCallum, M.L.; Trauth, S.E.; Mary, M.N.; McDowell, C. \& Wheeler, B.A. (2004). Fall breeding of the southern leopard frog (Rana sphenocephala) in northeastern Arkansas. Southeastern Naturalist 3: 401-408.

Meshaka, W.E., Jr. (2001). The Cuban Treefrog in Florida: Life History of a Successful Colonizing Species. University Press of Florida, Gainesville, Florida, USA.

Meshaka, W.E., Jr. \& Layne, J.N. (2015). The herpetology of southern Florida. Herpetological Conservation and Biology 10: 1-353.

MeshaKa, W.E., Jr. \& Marshall, S.D. (2011). Clutch characteristics of the southern leopard frog, Lithobates sphenocephalus (Cope, 1886), in Natchitoches, Louisiana. Bulletin of the Maryland Herpetological Society 47: 3637.

Meshaka, W.E., JR.; Delis, P.R. \& Mortzfeldt, S.A. (2011). Seasonal activity, reproductive cycles, and growth of the northern leopard frog, Lithobates pipiens (Schreber, 1782), in Pennsylvania. Bulletin of the Maryland Herpetological Society 47: 23-35.

Minton, S.A., Jr. (2001). Amphibians and Reptiles of Indiana, $2^{\text {nd }} e d$. Indiana Academy of Science, Indianapolis, Indiana, USA.

Mitchell, J.C. (1986). Life history patterns in a central Virginia frog community. Virginia Journal of Science 37: 262-271.

Mitchell, J.C. (2002). An overview of amphibian and reptile assemblages on Virginia's eastern shore, with comments on conservation. Banisteria 20: 31-45.

Mitchell, J.C. (2013). Emmett Reid Dunn and the early history of herpetology in Virginia. Banisteria 41: 27-39.

Mitchell, J.C. \& Pague, C.A. (2014). Filling gaps in life-history data: Clutch sizes for 21 species of North American anurans. Herpetological Conservation and Biology 9: 495-501.

Moore, J.A. (1949). Geographic variation of adaptive characters in Rana pipiens Schreber. Evolution 3: 1-24. 
Morrison, C. \& Hero, J.M. (2003). Geographic variation in life-history characteristics of amphibians: A review. Journal of Animal Ecology 72: 270-279.

Nicholls, R.J. \& Cazenave, A. (2010). Sea-level rise and its impact on coastal zones. Science 328: 1517-1520.

Noss, R.F.; Platt, W.J.; Sorrie, B.A.; Weakley, A.S.; Means, D.B.; Costanza, J. \& Peet, R.K. (2015). How global biodiversity hotspots may go unrecognized: lessons from the North American Coastal Plain. Diversity and Distributions 21: 236-244.

Orizaola, G. \& Laurila, A. (2016). Developmental plasticity increases at the northern range margin in a warm-dependent amphibian. Evolutionary Applications 9: 471478.

RAY, G.C. (1991). Coastal-zone biodiversity patterns. BioScience 41: 490-498.

Roble, S.M.; Chazal, A.C. \& Foster, A.K. (2000). A preliminary survey of amphibians and reptiles of Savage Neck Dunes Natural Area Preserve, Northampton County, Virginia. Catesbeiana 20: 63-74.

Sмiтh, P.W. (1961). The amphibians and reptiles of Illinois. Illinois Natural History Survey Bulletin 28: 1-298.
Stiles, R.M. \& Lannoo, M.J. (2015). Lithobates sphenocephalus: Fall breeding. Herpetological Review 46: 414.

Stuart, S.N.; Chanson, J.S.; Cox, N.A.; Young, B.E.; Rodrigues, A.S.L.; Fischman, D.L. \& WALler, R.W. (2004). Status and trends of amphibian declines and extinctions worldwide. Science 306: 1783-1786.

Trauth, S.E. (1989). Female reproductive traits of the southern leopard frog, Rana sphenocephala (Anura: Ranidae), from Arkansas. Proceedings of the Arkansas Academy of Science 43: 105-108.

Trauth, S.E.; Robison, H.W. \& Plummer, M.V. (2004). The Amphibians and Reptiles of Arkansas. Arkansas Fish and Game Commission, Little Rock, Arkansas, USA.

Urban, M.C. (2015). Accelerating extinction risk from climate change. Science 348: 571-573.

White, J.F., Jr. \& White, A.W. (2002). Amphibians and Reptiles of Delmarva. Tidewater Publishers, Centreville, Maryland, USA.

Wright, A.H. (1931). Life-Histories of the Frogs of Okefinokee Swamp, Georgia. The Macmillan Company, Ithaca, New York, USA.

ZAR, J.D. (1996). Biostatistical Analysis, $3^{\text {rd }}$ ed. Prentice Hall, Upper Saddle River, New Jersey, USA. 